\title{
Brasilien. Ein Land der Zukunft: dois autores, duas monografias, duas Weltanschauungen
}

\author{
[Brasilien. Ein Land der Zukunft: two authors, two monographies, two \\ Weltanschauungen]
}

http://dx.doi.org/10.11606/1982-8837233925

Tito Lívio Cruz Romão ${ }^{1}$

\begin{abstract}
Our main objective is to present a study on Heinrich Schüler, a German-Brazilian author who published a detailed book about Brazil. With his idea of "Brazil, a country of the future", he anticipated Stefan Zweig in almost three decades. A naturalized Brazilian, Schüler was Brazil's consular representative in Bremen and assistant consul in Hamburg, where he taught university courses on Brazilian culture. Basing on research performed in Brazilian and GermanBrazilian newspapers, we could compose a portrait of a man who transitioned between Brazilian and German diplomacy. Thus, he was well-regarded by some, but regarded with suspicion by others. If he showed himself to be a faithful citizen of Brazil, he also revealed himself to be a tireless defender of Germanism in Brazil. He defended the sending of "new German blood" to Brazil, in order to avoid that "the German-speaking colonies widely dispersed in the South of Brazil" had to be mixed "with the foreign elements". Examining Schüler's profile, we conclude that, if Zweig had read the consul's monography as a preparatory reading, he must have subsequently been shocked by Schüler's political ideas, since he would flirt with the Hitlerist intention of implanting Nationalsozialistische Deutsche Arbeiterpartei (NSDAP - in English, National Socialist German Worker's Party) cells in Brazilian German-speaking states.
\end{abstract}

Keywords: Heinrich Schüler; Stefan Zweig; country of the future; antagonistic cosmovisions.

Resumo: Nosso objetivo central é apresentar um estudo sobre Heinrich Schüler, cidadão teutobrasileiro autor de um minucioso livro sobre o Brasil. Com sua ideia de "Brasil, um país do futuro", antecipou-se a Stefan Zweig em quase três décadas. Brasileiro naturalizado, Schüler foi representante consular do Brasil em Bremen e cônsul-adjunto em Hamburgo, onde também ministrou cursos sobre cultura brasileira para universitários. Baseando-nos em pesquisas feitas em jornais brasileiros e teuto-brasileiros, logramos compor uma imagem de Schüler que, como mostram as análises, transitava facilmente entre as diplomacias brasileira e alemã. Justamente por isso, era bem visto por uns, mas com suspeição por outros. Se, por um lado, mostrava-se um fiel cidadão da pátria que o acolhera, por outro, revelava-se um incansável defensor do alemanismo no Brasil. Defendia o envio de "sangue novo alemão" para terras brasileiras, para evitar que "as colônias de expressão alemã muito dispersas no sul do Brasil" tivessem de se mesclar "com os elementos estrangeiros". Diante do perfil de Schüler, conclui-se que, se Stefan Zweig tiver lido a monografia do cônsul como leitura preparatória, posteriormente deve ter-se chocado com as ideias políticas desse homem que flertaria com a intenção hitlerista de implantar células do

\footnotetext{
${ }^{1}$ Universidade Federal do Ceará, Avenida da Universidade, 2683, Fortaleza, CE, 60170-002, Brasil. Email: cruzromao@terra.com.br. ORCID: 0000-0002-3195-3600
}

\section{(cc) BY-NC}


Nationalsozialistische Deutsche Arbeiterpartei (NSDAP - em português, Partido NacionalSocialista dos Trabalhadores Alemães) em estados germanófonos brasileiros.

Palavras-chave: Heinrich Schüler; Stefan Zweig; país do futuro; cosmovisões antagônicas.

\author{
« Dann zu Vargas: ein kleiner untersetzter Mann \\ mit scharfen wachen Augen, sehr behend und \\ beweglich, mehr als sein Französisch. $»^{2}$
}

Stefan Zweig

\title{
1 Introdução
}

Em 1941, o renomado biógrafo, ficcionista e pacifista judeu-austríaco Stefan Zweig lançou, no Brasil e em Portugal, a versão em português de seu livro Brasilien. Ein Land der Zukunft, que ganhou o título Brasil: país do futuro, na tradução de Odilon Galotti; de modo quase concomitante a editora Berman-Fischer publicava, em Estocolmo, a versão alemã, e o livro também era lançado em inglês nos Estados Unidos e na Inglaterra (na tradução de James Stern), em francês (traduzido por Claire Goll) e em sueco (na versão de Hugo Hultenberg). Críticos, comentadores e editores literários de língua alemã, como Volker Michels (ZWEIG, 1997), autor do posfácio de uma edição alemã da obra de Zweig, costumam denominá-la Monografie; na língua alemã, o termo não se circunscreve apenas àquele sentido que no Brasil "é utilizado por professores e alunos de graduação" em referência a "um trabalho acadêmico simples, de caráter não muito profundo, que serve como uma espécie de treino para futuros trabalhos científicos como a dissertação ou a tese" (COSTA 2012: 171). O termo alemão aproxima-se, muito mais, de um segundo sentido, mais rigoroso: “...refere-se à monografia como um trabalho escrito, pormenorizado, em que se pretende dar um tratamento profundo a algum tema particular de um ramo de conhecimento, ou a personagens, localidades, acontecimentos etc." (Ibidem: 171). De maneira análoga à segunda acepção de monografia, e como a própria origem do nome revela, uma Monografie alemã também encerra a ideia de um texto escrito sobre um tema específico, que é objeto de um estudo aprofundado. Nesta acepção, entendemos que tal conceito também pode ser aplicado a uma obra literária em que o autor aborde um tema em muitos pormenores, mas que, considerados o estilo, a forma e

\footnotetext{
${ }^{2}$ ZWEIG (1984: 406).
} 
a pertença a uma escola literária, não se insira apenas em uma visão de mundo científica, mas também estético-estilística e, por extensão, literária. No caso específico do livro de Zweig sobre o Brasil, trata-se de uma monografia sobre o personagem ou o lugar Brasil, na qual o autor descreve aspectos históricos, geográficos, sociológicos, antropológicos e culturais do mais extenso país da América Latina, colocando-o, de súbito, sob a mira do público leitor mundial que, se poucas informações detinha sobre essa terra sob a ótica geopolítica e historiográfica, muito menos conhecia pormenores - antigos ou recentes sobre o povo, as riquezas e os costumes brasileiros.

Perscrutando a monografia do Brasil escrita por Zweig, deparamo-nos com referências à pujança e ao porvir de um país que, justamente para alguém que se vira forçado a abandonar sua terra no continente europeu - onde a paz deixara de reinar e o nazifascismo estava na ordem do dia -, parecia ser sinônimo de paz étnica, harmonia social e promessa de futuro grandioso. Em sua chegada de navio ao Rio de Janeiro, em 21 de agosto de 1936, por ocasião de sua primeira viagem ao Brasil, de onde seguiria para uma reunião do PEN Clube em Buenos Aires, Zweig descreve seu encantamento com a paisagem que se descortinava perante seus olhos:

Conseguirei registrar tudo do Rio e não esquecerei demasiadas coisas! Pela manhã, a entrada no porto: um esplendor. Em primeiro lugar, as ilhas, emergindo do mar, verdes ou rochosas, e em seguida, na leve névoa matutina, o Corcovado com a cruz e o Pão de Açúcar, ambos se elevando como monólitos, e às suas margens, em baías maravilhosamente sinuosas, a cidade, sempre voltando a começar, sempre voltando a ser interrompida pelos promontórios que se estendem para baixo como os dedos de uma mão querendo mantê-la coesa. Nada mais belo se pode imaginar além dessa maneira adorável de uma cidade se espalhar e, entre um ponto e outro, os velozes ferry-boats à beira-mar: já se mescla ao cheiro de mar uma suave fragrância de terra, recebe-se um abraço suave, e a entrada no porto realmente [se dá] como uma calorosa recepção em países do sul, enquanto Nova Iorque saúda, de modo semelhantemente deslumbrante, com icebergs de pedra, retumbando triunfante, em nossos ouvidos, sua barulheira. Nova Iorque conclama, Rio espera, uma masculina, a outra feminina, e essas linhas ondulantes têm algo da forma de uma mulher que emerge das ondas, Vênus Anadiômene. (ZWEIG 1984: 399, tradução nossa) $)^{3}$

Esse arrebatamento que toma o escritor se repetiria durante sua breve permanência no Rio, quando também visitou São Paulo, Campinas e Santos, bem como em sua segunda viagem ao Brasil, quando, entre agosto de 1940 e janeiro de 1941, retornou à capital do país, mas também estendeu sua estadia a Salvador, Recife e Belém. Desde a primeira

\footnotetext{
${ }^{3}$ Os textos citados neste artigo e publicados originalmente em alemão sempre serão apresentados em nossa tradução em português. Isso vale para os trechos citados de obras de Stefan Zweig, Frederik Schulze, Heinrich Schüler etc. e para os jornais teuto-brasileiros publicados em alemão. Sempre que já houver uma versão brasileira da obra, será apontado o nome do respectivo tradutor nas Referências Bibliográficas.
} 
viagem já estava em curso o projeto de monografia sobre o país que, em setembro de 1941, escolheria não apenas como local de exílio, mas também como última morada até cometer o suicídio na companhia de Lotte, sua segunda esposa. Antes do triste desfecho, a relação com o Brasil, apesar dos primeiros encantos, também teve suas vicissitudes, como bem descreve seu célebre biógrafo judeu-brasileiro:

Em seis anos e meio, de 21 de agosto de 1936 a 22 de fevereiro de 1942, com apenas 319 dias vividos no Brasil, armou-se e desarmou-se uma paixão em que os amantes jamais se maltrataram e, no entanto, prejudicaram-se terrivelmente. "País do futuro", o benevolente título, manteve-se como estigma durante algumas décadas. E nele matou-se o desarvorado autor. Sabia que o acusavam de ter sido comprado pela máquina de propaganda do ditador Getúlio Vargas. Os acusadores, porém, desconheciam que o "preço" foi um visto de residência no momento em que os campos de concentração nazistas se enchiam com aqueles que não obtinham salvo-condutos para países neutros. (DINES 2012: 16)

Para preparar seu tratado sobre o país pelo qual se apaixonara, Zweig certamente leu algumas obras que lhe serviram como percurso preparatório rumo à monografia objeto deste artigo. Dines (2012: 421) relata em uma nota de rodapé na biografia em homenagem a Zweig que “a 'biografia' do livro brasileiro contém 12 cartas enviadas por Zweig para [Abraham] Koogan [seu editor no Brasil], a primeira em meados de setembro de 1940 e as demais entre 3/11/1940 e 1/8/1941". Também acrescenta que teriam sumido duas respostas de Koogan (24/2 e 9/4/1941), e que um post-scriptum dirigido a Benjamin W. Huebsch, antimilitarista e fundador da Editora B. W. Huebsch, "marca o término do trabalho". Dines (Ibidem: 403) atesta que o escritor não teria lido o livro Casa-Grande \& Senzala, pois o próprio Gilberto Freyre, em um depoimento datado de 5 de agosto de 1980, afirmou que, quando foram apresentados, Zweig “sequer o mencionou". Freyre ainda teria afirmado que Zweig escrevera sobre o "futuro com otimismo, sem conhecer nosso passado" (DINES 2012: 403). Dines igualmente destaca que Zweig não pudera usufruir dos dados contidos no livro Raízes do Brasil, lançado em 1936 por Sérgio Buarque de Holanda, como também não desfrutara dos conhecimentos que o etnólogo franco-belga Claude Lévi-Strauss lhe teria podido repassar, caso, por exemplo, o tivesse encontrado em sua primeira viagem a São Paulo. Nessa mesma época, prossegue Dines (Ibidem: 57), também não o aproximaram de Paulo Prado, “autor do clássico Retrato do Brasil, ensaio sobre a tristeza brasileira". Em seus Tagebücher [Diários] (Zweig 1984: 405), no dia 24 de agosto de 1936, faz referência a Afrânio Peixoto, médico, professor, literato e político baiano, que desde 1910 ocupava a cadeira 7 na Academia Brasileira de Letras, bem como ao então presidente do PEN Club do Brasil, Cláudio de Souza: 
Segunda-feira, 24 [de agosto de 1936]. Pela manhã, trabalho, entrevistas, caminhada pela cidade de que cada vez mais gosto. Uma diversidade e um colorido sem par. Em pequenos restaurantes, como feijoada e bebo cachaça, fumo belos charutos, tomo café (tão quente que um cachorro sai correndo e ganindo, se alguém lhe der uma cusparada de café), desfruto de um bom encontro com Cláudio de Souza, Peixoto e outros literatos, e sentirme-ia como se estivesse no paraíso, não fosse a pressão das conferências ainda por fazer. (ZWEIG 1984: 405 et seq., tradução nossa)

O autor fez uma visita a Petrópolis, onde se admirara ao ver bairros com nomes de províncias germânicas e encontrara moradores igualmente alemães, crianças louras e inclusive uma senhora que lhe servira café numa fazenda, falando muito bem alemão, além de ter afirmado que lera todos os livros de Zweig. E após o retorno, indica sua programação:

Então de volta à cidade [do Rio], onde faço uma refeição com o encarregado de negócios austríaco, Faccioli Grimeni, que me conta muitas coisas sobre o Brasil: todas as pessoas amam o país e a maneira especialmente amável e generosa de seus habitantes. Todos sentem que aqui se está preparando um grande futuro, sob a condição de que bastante gente e bastante capital venham até o país. (ZWEIG 1984: 403s, tradução nossa)

Nessas palavras, vê-se claramente a ideia de descrever o Brasil como uma terra de futuro promissor, o que acaba realizando, ao publicar sua monografia brasileira em 1941. Afrânio Peixoto escreveu o prefácio do livro publicado no Brasil, que também foi incluído na edição portuguesa e na espanhola, mas não nas edições em inglês e francês, tampouco no original alemão. Também não foi abrigada na retradução brasileira de Kristina Michahelles (ZwEIG 2006b), tendo sido substituída por um prefácio de Alberto Dines. Em suas palavras, Peixoto destaca o projeto literário e o grande presente dado pelo escritor ao país, além de alfinetar aqueles que se colocavam contra um livro que, como sustentavam as vozes contrárias, teria sido escrito sob os auspícios do ditador Vargas:

De tudo, este livro, este grande livro, livro de amor presente e esperança futura que sai em imensas edições, na América, na Inglaterra, na Suécia, na Argentina, em francês e alemão também - seis de uma vez... a menor, a brasileira... É o mais "favorecido" dos retratos do Brasil. Nunca a propaganda interesseira, nacional ou estrangeira, disse tanto bem do nosso país, e o autor, por ele, não deseja nem um aperto de mão, nem um agradecimento. Amor sem retribuição. Amor de caboclo supercivilizado: a namorada vai saber agora e ficará confusa de tanto bem querer. Ele, porém, já partiu. Deixou apenas esta declaração. Declaração de envaidecer à formosura mais presumida. Os "pátriaamada", os "ufanistas" ficarão de cara à banda, pois ninguém até hoje escreveu livro igual sobre o Brasil. (ZWEIG 1941: 7 et seq.)

Quando Peixoto escreveu o prefácio, Zweig e sua segunda esposa Lotte ainda não haviam chegado ao exílio brasileiro, por isso a menção de que Zweig já partira. $O$ acadêmico também sublinha a "esperança futura" que o Brasil de então representava. No tocante ao título da obra de Zweig em questão, lembre-se que, na versão brasileira mais 
recente, o mesmo livro foi intitulado Brasil: um país do futuro (ZwEIG 2006b). Essa questão reflete a pluralidade de escolhas encontradas nas traduções do título original em diferentes línguas, como muito bem observa Dines:

Identificado o autor da façanha de encontrar a entonação épica para uma das obras que, sem ela, seria apenas curiosa, resta saber quem surrupiou o artigo indeterminado do título Brasilien, ein Land der Zukunft. Sem o artigo, a expressão ganhou determinação, passou a ser afirmativa, caso das versões inglesa (Brazil, Land of the Future), português (Brasil, país do futuro), espanhola (Brasil, país del futuro) e mesmo francesa (Le Brésil, terre de l'avenir). "Brasil, um país do futuro" admite outros países nas mesmas condições. Na edição brasileira, a supressão do artigo pode ter sido um agrado de Koogan ao governo Vargas, ou obediência à sintética opção inglesa. Funcionou. Não foi dele uma das mais felizes criações numa excepcional coleção de títulos. (DINES 2012: 426)

Observe-se, ainda, que o título de uma edição mais recente do livro publicada na Espanha (ZWEIG 2006a) também prescinde de todo e qualquer artigo: Brasil: país de futuro. Nas primeiras edições em língua inglesa, na tradução feita por Andrew St. James - nome cristão do judeu James Stern, como nos alerta Dines (2012: 424) - e publicada nos Estados Unidos (ZWEIG 1941) e em países da comunidade britânica (ZWEIG 1942), não se usou o artigo (Brazil: land of the Future); no entanto, numa versão da autoria de Lowell A. Bangerter e publicada mais recentemente nos Estados Unidos (ZWEIG 2000), adotou-se o artigo indefinido: Brazil: $\underline{\text { a }}$ Land of the Future. Em suas cuidadosas pesquisas sobre o título dado por Zweig ao livro dedicado ao Brasil, Dines tenta refazer o percurso realizado pelo ficcionista e pelo editor. Meses antes da publicação, quando Zweig se encontrava em Nova Iorque, essa questão ainda estava pendente: "Antes de escolher o próximo destino, precisa de um título para o seu livro. O criativo titulador dos maiores sucessos literários dessa vez não consegue uma frase cintilante e instigante, não obstante a eloquência de certas passagens" (Ibidem: 424). Como recorda Volker Michels (ZwEIG 1997: 297) em uma carta escrita a Abraham Koogan aos 22 de abril de 1941, Zweig afirma: "Com relação ao título, decidimo-nos por "Brasilien - Land der Zukunft" [Brasil - País do Futuro], e acho que também caberia para a edição brasileira". Em seu vasto estudo, Dines (Ibidem: 460ss) reflete sobre "a imagem da terra do porvir" já expressa por Pêro Vaz de Caminha em sua Carta ao rei D. Manuel de Portugal; ademais, menciona o conde francês Arthur de Gobineau, que, apesar de suas terríveis teses sobre a mestiçagem, reconhecia o Brasil como uma terra promissora. Merece também menção a frase do diplomata e conde austríaco Anton Prokesch von Osten, endereçada a Gobineau em 1868, visando a convencê-lo a aceitar o cargo de attaché no Brasil, a qual figura como epígrafe de abertura da monografia de Zweig sobre o Brasil: "Um país novo, um porto magnífico, 
a distância da mesquinha Europa, uma terra de futuro e um passado quase desconhecido que convida o estudioso a pesquisas, uma natureza esplêndida e o contato com novas ideias exóticas" (ZwEIG 1997: 5, tradução nossa). Dines (2012: 460) também nos lembra a publicação de um livro do holandês N. R. de Leuw, de 1909, intitulado Brazilië, een Land der Toekomst [Brasil, um país do futuro], "calhamaço de quatrocentas páginas”, e, por fim, o livro do "diplomata alemão Heinrich Schuler [sic.]" intitulado "Brasilien, ein Land der Zukunft, antecipação exata do título original de Zweig”. Sobre Schüler, Dines explica em uma nota de rodapé: "Schuler [sic!] foi o fundador do primeiro instituto alemão de estudos latino-americanos em Aix-La-Chapelle (Aachen)" (Ibidem: 460).

Neste artigo, nossa atenção estará voltada especificamente à pessoa de Heinrich Schüler - ou, aliás, Henrique Schüler - e à sua obra cujo título é retomado por Zweig em sua monografia sobre o Brasil. Vê-se claramente que o título escolhido por Schüler e reprisado por Zweig coincide, por seu turno, com aquele dado por N. R. Leuw a seu livro. Frise-se que há um intervalo de três anos entre a publicação do livro do autor neerlandês e a edição da obra de Schüler na Alemanha. Apenas podemos supor que Zweig tenha tido acesso ao pormenorizado relato feito por Schüler sobre o Brasil, de maneira análoga ao fato de que, como aponta Marlene Eckl (2009: 61), Heinrich Eduard Jacob, antes de vir ao Brasil em 1932, preparara-se minuciosamente e, para tanto, lera o livro de Schüler. Jacob viera a primeira vez ao país na viagem do Zeppelin ao Brasil, mas em seguida também resolveu estudar e escrever sobre diversos temas brasileiros, por exemplo, o café. Eckl destaca as palavras do autor e viajante alemão que, ao se referir ao Brasil, reconheceo como um país dezoito vezes maior que a Alemanha, mas com apenas a metade da população alemã, e arremata: "País de um futuro, Brasil”" (ibidem: 55). Acresça-se que, em um artigo disponível online, Gerhard Drekonja-Kornat (2013), também faz a seguinte reflexão:

Chama-se "Brasilien. Ein Land der Zukunft" [Brasil. Um país do futuro] um texto publicado em 1912, em Stuttgart, pelo cônsul Heinrich Schüler. Stefan Zweig não terá lido, em 1936 (antes de sua primeira viagem ao Brasil), o referido livro na Biblioteca da Universidade de Viena? Pois exatamente esse título ele utilizou para o seu próprio livro sobre o Brasil, publicado no exílio pela editora Berman-Fischer em Estocolmo. (DREKONJA-KORNAT 2013, tradução nossa)

A seguir, abordaremos alguns detalhes relacionados ao livro Brasilien. Ein Land der Zukunft, de Heinrich Schüler para, em um segundo momento, dedicarmo-nos aos pormenores que encontramos sobre sua vida, que aqui apresentaremos à guisa de apanhado biográfico breve e lacunar. 


\section{$2 \bigcirc$ livro de Heinrich Schüler}

Ao publicar em 1912 seu livro Brasilien. Ein Land der Zukunft [tradução literal: Brasil. Um país do futuro], Heinrich Schüler adiantou-se a Stefan Zweig em quase três décadas. Ao buscarmos detalhes concretos e fidedignos sobre esse homem, normalmente nos deparamos com poucos detalhes: tratava-se de "um imigrante de língua alemã" (SoUSA 1996: 14), "um diplomata alemão" (DINES 2012: 460), "um "cônsul” (DREKONJAKORNAT 2013, tradução nossa), "um cônsul alemão" (SCHUlze 2016: 103, tradução nossa) ou "um alemão que já vivia há meio século no Brasil”" (BISPO 2015) e que ajudara a criar "o primeiro Instituto Alemão de Estudos Latino-Americanos" (BRIESEMEISTER 2014, tradução nossa; Dines, 2012, p. 460). No livro escrito por H. Schüler em homenagem a Dona Leopoldina (SCHÜLER, 1954, tradução nossa), Rudolf Grossmann, então diretor do Instituto Ibero-Americano de Pesquisa da Universidade de Hamburgo fez, no prefácio, a seguinte referência ao diplomata brasileiro: "Seus inúmeros amigos, que conquistou nas décadas de atividades consulares na Alemanha, irão recepcioná-lo com a mesma gratidão e alegria que seus compatriotas brasileiros". Por outro lado, um estudo mais recente revela detalhes de seu envolvimento direto com o movimento hitlerista no Brasil durante os anos 1930 (SCHULZE 2016). Neste artigo, tentaremos trazer a lume outros pormenores sobre o cônsul e autor Heinrich Schüler, numa tentativa de melhor vislumbrar tanto as ideias contidas em seu livro supramencionado quanto a própria pessoa desse teuto-brasileiro que escreveu outros livros sobre temas brasileiros. Além da obra em epígrafe, Schüler escreveu pelo menos três livros dignos de menção, todos em língua alemã. No primeiro, intitulado Brasilien von heute [tradução livre: Brasil de hoje] e publicado em Berlim em 1910 pela D. Dreyer \& Co. Verlagsbuchhandlung, o autor discorre sobre o governo de Campos Sales (1898-1902). Também publicou um romance intitulado Unterm Kreuz des Südens [tradução livre: Sob o Cruzeiro do Sul] ${ }^{4}$,

\footnotetext{
${ }^{4}$ No final do livro Unterm Kreuz des Südens (SCHÜLER 1927), encontram-se duas resenhas jornalísticas sobre o livro Brasilien. Ein Land der Zukunft, de Heinrich Schüler, a saber: a) "Na verdade, a adição ao título das palavras "ein Land der Zukunft" ["um país do futuro"] já se presta para despertar no leitor o interesse pela obra. Mas quem se dedicar a essa temática encontrará, na leitura deste livro, ainda mais coisas do que lhe foi prometido. O autor, um teuto-brasileiro, estabeleceu em sua obra uma intenção que se manifesta em cada um dos capítulos. Pretende apresentar diante de nossos olhos o Brasil, esse país inesgotavelmente rico, a fim de que possamos testemunhar sua riqueza e, por outro lado, fomentar, através de nosso interesse, o crescimento desse país abençoado por Deus e pela natureza. A obra foi escrita com amor. Em todas as parte, isso se faz notar... A abundância do material ali reunido produz um efeito tão convincente que somente se pode esperar que o futuro do Brasil prometido pelo autor possa ser, em breve, fomentado e ampliado por nós alemães” (jornal Weserzeitung, de Bremen); b) “... Enche-nos de orgulho vermos Schüler constatar que a força e a inteligência alemãs também marcham, no outro lado do mundo,
} 
Romão, T. L. C. - Brasilien. Ein Land der Zukunft

em 1927, pela Deutsche Verlags-Anstalt de Berlim. Um terceiro livro ganhou o título Dona Leopoldina, die erste Kaiserin von Brasilien [tradução livre: Dona Leopoldina, a primeira imperatriz do Brasil] e foi publicado em 1954 pelo Instituto Beneficente e Genealógico Frederico Mentz, em Porto Alegre; consiste em uma narrativa "fiel à verdade" ${ }^{5}$ sobre a vida da austríaca Carolina Josefa Leopoldina Francisca Fernanda de Habsburgo-Lorena, filha do imperador austríaco Francisco I e de sua segunda esposa, a imperatriz Maria Teresa de Nápoles e Sicília, que se casaria aos 20 anos com Dom Pedro de Alcântara, herdeiro do trono imperial brasileiro.

A edição do livro de Schüler sobre o Brasil utilizada na redação deste artigo foi publicada em 1912 pela editora alemã Deutsche Verlags-Anstalt (Stuttgart/Leipzig) e compõe-se de 479 páginas, 115 figuras, 16 gravuras e 2 mapas. Prenhe de dados históricos, geográficos, econômicos, jurídicos, estatísticos etc., trata-se de um minucioso compêndio sobre o Brasil. Na introdução, o próprio autor se manifesta com estas palavras:

O presente livro pretende dirigir-se a todos os que se interessam pelo Brasil e pelas relações desse país com a Alemanha. Recorrendo a inúmeras fontes públicas e privadas, e também à literatura especializada - aproveito para mencionar especialmente a obra do "Centro Industrial" e a brochura do cônsul imperial E. Heinze sobre a erva mate -, aqui trago experiências colhidas ao longo de muitos anos, e que ora se vêm manifestar.

Há um quarto de século estou vivendo no Brasil, que, para mim, tornou-se uma segunda pátria. Ali tenho me mantido em meio à vida cotidiana e à luta pela existência.

Tive o privilégio de perscrutar a alma do povo luso-brasileiro e a alemanidade brasileira, e passar a conhecer as molas mestras que fazem funcionar o admirável progresso do país.

Com justificado orgulho posso constatar que nós, teuto-brasileiros, prestamos grandes serviços à nossa nova pátria, mas também provamos que o amor à nova pátria não deve resultar em uma renúncia à antiga. A atenção de que goza a cultura alemã no Brasil, o fato de haver nesse país cerca de 800 escolas de expressão alemã, muitas igrejas, jornais e associações alemães, e o fato de as transações comerciais com a Alemanha amontarem a centenas de milhões de marcos, tudo isso é, em boa parte, obra nossa.

O livro foi escrito a partir dessa perspectiva e almeja dar uma pequena contribuição para aumentar o conhecimento do nosso florescente país na Alemanha. (SCHÜLER 1912: VII, tradução nossa)

No que tange às fontes utilizadas por Schüler e mencionadas na citação acima, uma pesquisa em jornais da época que circulavam no Brasil revela que o livro não foi recebido apenas com admiração e respeito. Numa matéria intitulada Neue Südamerika-

na linha de frente; é perfeitamente adequado que amplos círculos também sejam esclarecidos sobre o país do futuro, tão importante para nós e para nosso comércio" (jornal Deutsche Tageszeitung, de Berlim).

5 "Wahrheitsgetreue[n] Erzählung" (tradução nossa), conforme o prefácio escrito por Maria F. Rohde (SCHÜLER, 1954).

Pandaemonium, São Paulo, v. 23, n. 39, jan.-abr. 2020, p. 25-56 
Romão, T. L. C. - Brasilien. Ein Land der Zukunft

Literatur [Nova Literatura Sul-Americana], publicada no dia 15 de abril de 1912 pelo Deutsche Zeitung ${ }^{6}$ (TROPPMAIR 1912), de São Paulo, o articulista que se assina apenas como Dr. B. analisa diferentes obras então recém-lançadas no subcontinente. Após lamentar a existência de poucas novas obras alemãs sobre temas brasileiros, em contraste direto com os interesses econômicos e nacionais existentes entre Brasil e Alemanha, o crítico faz uma resenha do livro Brasilien. Ein Land der Zukunft, lançado por Heinrich Schüler - ao preço de 10 marcos por exemplar - pela editora Deutsche Verlags-Anstalt de Stuttgart. Da mesma maneira, frisa que, em seus 25 anos de vida no Brasil, o Sr. Schüler decerto tivera a oportunidade de conhecer muito bem o país e seu povo do Rio de Janeiro até o Sul. Salientando que Schüler recorrera a várias fontes privadas e oficiais, para além de bibliografia especializada, Dr. B. pôs em relevo o uso da brochura sobre a erva mate escrita pelo cônsul imperial alemão no Paraná, E. Heinze, e da obra de referência publicada pelo Centro Industrial do Brasil, para assim acusar o autor de plágio:

Na verdade, uma tradução dessa obra teria sido louvável e útil, se como tal houvesse sido caracterizada e renovada mediante uma atualização das estatísticas obsoletas. Porém, promover sua tradução de partes da obra que, como se sabe, era uma publicação comemorativa e para fins de divulgação da Exposição Nacional de 1908, dando a entender que estaria escrevendo com base em observações e experiências próprias e que teria recorrido a várias fontes, é um acinte. Cumpre imediatamente indagar-se "Cui bono?" e dar como resposta que se trata mesmo de trabalho encomendado e pago, que o livro não passa de uma publicação com fins de propaganda que está sendo enviada mundo afora para enganar o público inexperiente, sob a bandeira das próprias observações e do amor à alemanidade. Chegamos a essa conclusão graças ao primeiro capítulo "Retrospectiva da história do Brasil do descobrimento ao presente", que é tão deficiente quanto na tradução francesa condensada, ao passo que a introdução histórica redigida por Capistrano de Abreu no original é uma peça magistral, assim como o panorama histórico do século XIX, da autoria do barão Homem de Mello, que, apesar de sua concisão, segue uma boa orientação. (TROPPMAIR 1912, tradução nossa)

De forma incisiva, o jornal alemão de São Paulo faz uma crítica feroz à monografia brasileira de Schüler, colocando-nos perante à seguinte situação: se algum plágio - pelo menos no tocante ao título - tiver sido praticado por Stefan Zweig ao publicar sua monografia sobre o Brasil, o articulista do Deutsche Zeitung paulistano apresenta sobejantes motivos que apontam para uma possível cópia perpetrada por Schüler em relação tanto à publicação do Centro Industrial do Brasil quanto ao texto do cônsul alemão E. Heinze. Ao aprofundar sua crítica, o jornalista adianta que o livro de Schüler peca por imprecisões históricas sobre D. Pedro II, a queda do Império e a

\footnotetext{
${ }^{6}$ Este trabalho apoia-se em pesquisas realizadas junto ao acervo digitalizado da Biblioteca Nacional Digital, ao portal do Instituto Martius-Staden e ao serviço de digitalização de jornais de língua alemã da Unesp.
}

Pandaemonium, São Paulo, v. 23, n. 39, jan.-abr. 2020, p. 25-56 
instauração do regime republicano. De resto, objeta que nos capítulos seguintes Schüler sequer se dera ao trabalho de pesquisar os dados mais recentes em documentos oficiais, tais como relatórios administrativos dos ministérios, mensagens presidenciais, atas da Comissão de Orçamento, o Brazilian Yearbook, as sinopses anuais publicadas pelo Jornal do Commercio e uma série de outras possibilidades. Ainda ressalta que na página 161 Schüler chega a afirmar que se reporta aos números das exportações referentes a 1906, porque "infelizmente" não fora possível ter acesso a dados mais recentes. Tal procedimento prejudicaria o caráter de divulgação que esse livro deveria ter, pois no prefácio é inequívoco que o ano de referência é 1911. Outra forte crítica é feita à sugestão de Schüler sobre a necessidade de os alemães importarem mel de abelha das regiões germanófonas do sul do Brasil, o que levaria a Alemanha a ocupar o segundo lugar como importador de produtos brasileiros, ficando à frente dos britânicos. $\mathrm{O}$ articulista reclama que o autor deveria também informar como se resolveria o problema que passariam a ter os apicultores alemães mediante a concorrência do mel oriundo do Brasil. Ademais, indaga se não seria mais plausível exportar o mel do sul do Brasil para o Rio de Janeiro e São Paulo, onde supostamente havia deficiência nesse tipo de produção. Elogios são tecidos à excelente qualidade das figuras e às ilustrações da capa feitas sobre tecido, apesar de algumas reclamações sobre a má qualidade das gravuras de Petrópolis, Santos e São Paulo, e sobre o pequeno número de gravuras retratando a alemanidade sulbrasileira. Por fim, Dr. B. resume que "o livro de Schüler não é, absolutamente, o trabalho sobre o Brasil que esperamos conforme o interesse alemão" (TROPPMAIR 2012, tradução nossa).

Há de se supor que a reação negativa do Deutsche Zeitung aos aspectos históricos descritos por Schüler sobre o Brasil do século XIX foi consequência direta do posicionamento político do jornal, que possivelmente ainda se pautava por ideais monárquicos. Lendo-se alguns trechos de Schüler sobre D. Pedro II, o imperador é descrito sobremaneira como um homem que fora criado sem pai e alçado ainda menino a uma condição de regente, fato que lhe custara demasiadamente caro. Além disso, o imperador também é mostrado como alguém que não conseguia ter bom trânsito nem com apoiadores nem com oposicionistas. Sobre a postura do Deutsche Zeitung, vejam-se estas reflexões publicadas no portal do Instituto Martius-Staden ${ }^{7}$ :

\footnotetext{
${ }^{7}$ Acesso ao Deutsche Zeitung disponível em: https://bibdig.biblioteca.unesp.br/handle/10/8047. Acesso em: 14 mar. 2019.
}

Pandaemonium, São Paulo, v. 23, n. 39, jan.-abr. 2020, p. 25-56 
Romão, T. L. C. - Brasilien. Ein Land der Zukunft

Os jornais em língua alemã no Brasil refletiam o ambiente político em curso na Alemanha. Eram fiéis à monarquia e ao Estado alemão-nacionalista. Essa era a base do Germania. Porém, com o tempo, o jornal se tornou cada vez mais liberal. A colônia alemã paulistana reagiu a esse posicionamento e muitos leitores se afastaram do Germania. Em 1896, quando Willy Epstein redigiu um artigo polêmico sobre o aniversário do Imperador, grande parte dos leitores abandonaram o jornal. Em consequência, foi fundado o Deutsche Zeitung [Jornal Alemão], em 12 de junho de 1897 por Dr. Johann Paul Lehfeld e Carlos Jepp, publicado semanalmente. A partir de 1906, com Rudolf Troppmair à frente, o jornal tornou-se diário, ampliou o espaço destinado à publicidade e tornou-se o veículo mais importante da população de língua alemã de São Paulo. (ROTHFUSS 2014)

$\mathrm{Na}$ mesma reportagem, o jornalista do Deutsche Zeitung também se dirigiu expressamente à pessoa do então embaixador brasileiro em Bruxelas, Manuel de Oliveira Lima $^{8}$ :

Até mesmo o ministro brasileiro em Bruxelas, Sr. Oliveira Lima, que escreveu um prefácio para o Sr. Schüler, chega a outras conclusões, nas conferências recentemente aqui anunciadas, sobre a formação da nação brasileira, D. Pedro II e seu tempo; e no que concerne à fundação da República, veste o manto do silêncio diplomático. O Sr. Schüler, ao contrário, ao descrever o período republicano, envereda pela exaltação aos homens que ora estão no poder ou poderão voltar a assumir o poder. (TROPPMAIR 1912)

Confirmando a informação do jornal, o livro de Heinrich Schüler realmente contara com um prefácio de Manuel de Oliveira Lima, um estudioso que se destacou como jornalista, escritor, historiador, professor e diplomata. Na opinião do ministro, os livros alemães sobre o Brasil são bem menos conhecidos que obras inglesas e francesas sobre o mesmo tema, pois poucos são os brasileiros que dominam o alemão. Sublinha que é entre as obras alemãs sobre o Brasil que se encontram as mais interessantes. E, ao lado de célebres eruditos e pesquisadores alemães, faz despontar o nome de Heinrich Schüler:

Nenhum viajante do século XVI alcança Hans Stade [sic] em descrições realistas e ao mesmo tempo pitorescas; nenhum erudito do século XIX supera Spix e Martius em opulência, minuciosidade e originalidade das observações; nenhum historiador pode perfilar-se ao lado de Handelmann quanto ao significado de suas comprovações científicas e à perspicácia de suas conclusões científicas. Publicaram excelentes obras nas quais os progressos feitos pelo Brasil foram, podemos afirmá-lo, examinados, avaliados e abordados em diferentes e sucessivas épocas. $\mathrm{E}$ a esse gênero também pertence esta obra do Sr. Heinrich Schüler, para a qual me solicitou um prefácio. (SCHÜLER 1912: V)

É evidente que Oliveira Lima dispensou uma atenção especial ao compêndio publicado por Schüler. O livro chama a atenção por seu grande número de informações, como denota sua divisão em 23 capítulos acompanhados de muitas tabelas com dados estatísticos, além de muitas figuras e gravuras apensas. Em 1912, além da primeira edição do livro, seguiram-se uma segunda e uma terceira. Em 1919 surgiu uma quarta edição alterada e continuada. Em 1921 foi publicada uma edição melhorada. Em 1924 surgiu a

\footnotetext{
${ }^{8}$ Nascido em Recife no ano de 1867, falecido em Washington no ano de 1928. Cf. Forster (2011).
}

Pandaemonium, São Paulo, v. 23, n. 39, jan.-abr. 2020, p. 25-56 
sexta e última edição de que se tem notícia, a qual, além da abundância temática, do grande número de tabelas e figuras, também trazia dezenove gravuras. Na edição utilizada neste trabalho - a terceira publicada em 1912 -, Schüler apresenta a seguinte divisão em capítulos: 1.Retrospectiva da História do Brasil desde o descobrimento; 2. População e imigração; 3. A Constituição; 4. Finanças; 5. Comércio internacional; 6. O café; 7. O fumo; 8. A borracha; 9. O algodão; 10. O chá-mate ou chá do Paraná; 11. A cana-deaçúcar; 12. O cacau; 13. A vinicultura; 14. A fruticultura no Brasil; 15. Temas variados sobre as plantas brasileiras; 16. Cereais, leguminosas e tubérculos; 17. A madeira e sua exploração; 18. A pecuária e as indústrias vinculadas a esse setor; 19. Caça, pesca e anfíbios; 20. A mineração; 21. A indústria; 22. A navegação; e 23. Ferrovias.

Sobre Schüler, Oliveira Lima ainda tece os comentários a seguir, que julgamos importantes neste estudo, por poderem ser contrastados posteriormente com outros dados encontrados em jornais brasileiros e teuto-brasileiros - de língua portuguesa e/ou alemã - em circulação naquela época. Tais informações serão úteis para compormos uma imagem - ainda que incompleta - de Heinrich Schüler, um homem sobre o qual parece haver poucos estudos biográficos e bibliográficos disponíveis:

Não considero necessário [escrever] um semelhante prefácio, porque o autor é conhecido em ambos os países como escritor justo e criterioso, mas o faço com prazer ainda maior, por eu ser o primeiro a reconhecer a profundidade e a larga visão na seleção das análises que ele realizou para publicar. O Sr. Schüler também deu provas dessas suas qualidades em seu trabalho como correspondente do Reporter Brazileiro, tendo criado um admirável órgão, através do qual propaga na imprensa europeia notícias breves, concisas, não condicionadas a quaisquer motivos, além de serem convincentes quanto ao desenvolvimento do país, eximindo-se de quaisquer artigos vaidosos que ninguém leria sem olhares desconfiados ou um sorriso irônico. (SCHÜLER 1912: VI, tradução nossa)

As palavras de Oliveira Lima revelam sua especial consideração por Schüler, em quem reconhecia não apenas o escritor, mas também o correspondente jornalístico. Sobre a relação próxima entre o embaixador brasileiro e o autor, vejam-se ainda estas considerações feitas por Antônio Alexandre Bispo, musicólogo e professor brasileiro no Instituto de Musicologia da Universidade de Colônia (Alemanha):

Manuel de Oliveira Lima escreveu em Bruxelas, em 1911, prólogo à obra a pedido do autor e no qual salienta, com a sua autoridade, a anuência e o reconhecimento por parte do Brasil. O fato de Heinrich Schüler ter solicitado palavras de abertura ao representante oficial do país em Bruxelas explica-se não apenas pelo renome e autoridade do Ministro, mas também pelos estreitos elos de recíproco respeito e amizade. Esse respeito por Heinrich Schüler manifestar-se-ia no seu pronunciamento por ocasião da despedida de Oliveira Lima em banquete oferecido pela colônia brasileira de Bruxelas, em 1911, quando Schüler, em português, anunciou nada menos que o governo imperial alemão oferecera a Oliveira Lima uma cátedra na universidade de Aachen. (BISPO 2015) 
Em um artigo publicado no portal da Deutscher Lusitanistenverband [Associação Alemã de Lusitanistas] $]^{9}$, o romanista alemão Dietrich Briesemeister ajuda-nos a conhecer um tanto mais sobre o perfil e o papel de Heinrich Schüler, ao lançar alguma luz sobre a contribuição dada por esse teuto-brasileiro no âmbito dos estudos culturais relativos ao Brasil, tema seguramente caro ao Instituto Ibero-Americano de Berlim, à frente do qual Briesemeister esteve entre 1987 e 1990. São estas as suas palavras:

Em Aachen, onde estava sediada uma Escola Técnica Superior, em 1912 já fora fundado o Instituto Teuto-Sul-Americano - o primeiro na Alemanha dedicado a Estudos LatinoAmericanos - na qualidade de associação. Esteve sob a direção do professor de Geodésia Paul Gast e contou com o apoio de Bernhard Schädel, bem como de Heinrich Schüler, o autor do livro Brasilien. Ein Land der Zukunft [Brasil. Um país do futuro] (1912, com seis edições até 1927), um título que Stefan Zweig retomou em 1941. Como países do futuro, além dos Estados Unidos também se louvavam Argentina, Romênia e Ucrânia. Schüler trabalhou em Bruxelas com o embaixador, escritor e erudito brasileiro Manuel de Oliveira Lima, cofundador da Academia Brasileira de Letras. (BRIESEMEISTER 2014: 9, tradução nossa)

Ainda no contexto do Instituto Teuto-Sul-Americano criado em Aachen e sua relação com Schüler, Frederik Schulze, pesquisador do Seminário Histórico da Westfälische Wilhelms-Universität, vinculado à cátedra de História Extra-Europeia em Münster (Alemanha), faz-nos ver com mais clareza algumas características pessoais de Schüler. As ideias de Schulze estão descritas com fartos pormenores em um livro resultante de sua tese de doutorado sobre emigração como projeto nacionalista, dando especial ênfase à alemanidade e aos discursos coloniais fracassados no sul do Brasil entre os anos de 1824 e 1941. O pesquisador não apenas explica que Schüler foi "cônsul alemão" no Rio de Janeiro, mas também informa que ele "antes trabalhara no Instituto Teuto-Sul-Americano, onde escreveu um livro sobre cultura e civilização brasileira ${ }^{10 "}$ (SCHUlzE 2016, tradução nossa). Ademais, também realça detalhes sobre o passado político de Schüler, mais precisamente sobre a ligação do cônsul com as tentativas de infiltração e expansão nos estados germanófonos do Brasil feitas pelo Partido NacionalSocialista dos Trabalhadores Alemães (NSDAP), através de uma AO (Auslandsorganisation = organização estrangeira), isto é, uma célula brasileira do partido de Hitler. No trecho a seguir, Schulze apresenta detalhes sobre a afiliação de associações sul-rio-grandenses a confederações de associações da Alemanha de Hitler:

Uma série de associações do Rio Grande do Sul afiliou-se a confederações de associações alemãs. Os nacional-socialistas obtiveram êxito sobretudo em Santa Cruz do Sul, onde conseguiram cooptar a maioria das associações. Em 1936, a célula NSDAP/AO

\footnotetext{
${ }^{9}$ Cf. http://www.dpg-report.de/buch.htm. Acesso em: 14 mar. 2019.

${ }^{10}$ A edição do livro de H. Schüler a que F. Schulze se refere é de 1924.
} 
participou, juntamente com o consulado no Rio de Janeiro, da fundação da Federação 25 de Julho, que tinha por fito organizar, do ponto de vista cultural, os imigrantes alemães e seus descendentes. A conclamação para a fundação da entidade, assinada por Heinrich Schüler, apresentava a preservação da 'alemanidade' e a lealdade ao Brasil como ideias centrais da associação. Não obstante, nos bastidores se impunham esforços da NSDAP/AO para que sua influência se estendesse aos descendentes dos imigrantes e à evolução da política interna [brasileira]. (SCHULZE 2016: 103, tradução nossa)

A data "25 de julho", presente no nome da federação de cuja fundação o NSDAP, através de sua célula brasileira, participou com a anuência de Heinrich Schüler, remete à data em que oficialmente se instalaram em São Leopoldo (RS) os primeiros colonos alemães, mais precisamente, colonos prussianos (SCHULZE 2016). Nos propósitos centrais dessa federação vemos ideias defendidas por Schüler, e aqui resumidas, tanto na fidelidade à terra natal quanto na lealdade demonstrada à nova pátria. Com sua experiência como cônsul brasileiro na Alemanha e sua vivência no Brasil, Schüler devia ser consciente dos rumos da política interna alemã em 1936, sabendo que isso fatalmente teria influência direta na evolução da política interna brasileira em geral e notadamente nos estados confederados com marcante presença alemã. Em seu livro, Schulze mantém as palavras 'alemão' e 'alemanidade' entre aspas simples, assim explicando sua opção:

Visando a identificar o caráter constitutivo dos conceitos 'alemanidade' e 'alemão' no sentido de uma categoria cultural e, também, a mostrar que se trata de conceitos e de conceitos-fonte da época, essas palavras aqui serão grafadas entre aspas simples. Afinal de contas, 'alemanidade' não designava, em primeira linha, cidadãos alemães, que àquela época eram normalmente chamados de 'alemães imperiais' [termo vigente entre $1871 \mathrm{e}$ 1945], mas pessoas que falavam a língua alemã e às quais os representantes da 'alemanidade' conferiam o grau de membros da 'alemanidade' cultural. Tratava-se principalmente de todos os imigrantes alemães e seus descendentes que já haviam obtido a nacionalidade, mas também podia abranger outros falantes de alemão que amiúde também participavam dos cultos religiosos celebrados por religiosos alemães. 'Alemanidade' não era uma categoria desprovida de valores, mas acarretava, muito mais, uma série de concepções idealizadas que desembocavam em um sentimento de superioridade. (SCHULZE 2016: 17, tradução nossa)

Como mostra a explicação de Schulze, o termo 'alemanidade' traz em si um potencial nacionalista que, se tivesse logrado alastrar-se, certamente teria tido fortes consequências nas relações entre o Brasil e a Alemanha. Como veremos mais abaixo, esse vocábulo será um termo-chave nas ideias defendidas por Schüler - embora o autor sempre faça questão de reiterar seu apreço por sua segunda terra, sublinhando seu status de teutobrasileiro. As consequências advindas de um fortalecimento da alemanidade àquela época devem ser elucubradas, aqui, sob o signo do regime de Hitler e, sobretudo, considerando-se as associações ultranacionalistas que já começavam a surgir no Rio 
Grande do Sul - embora igualmente houvesse grande rejeição a elas -, motivadas pela potência imperialista alemã que se firmava com os nazistas.

Ao escrever sua monografia brasileira, o Brasil de Heinrich Schüler, "o maior país do continente sul-americano" (SCHÜLER 1912: 1, tradução nossa), tinha no início do século XX uma população de apenas 22 milhões de habitantes. $\mathrm{O}$ autor faz um longo e pormenorizado relato da história brasileira desde o momento em que "o almirante português Pedro Álvares Cabral tomou posse oficialmente do novo país, em Porto Seguro, em nome do rei Dom Manuel" (Ibidem: 2, tradução nossa), passando pela ocupação holandesa, pela proclamação da independência, por levantes regionais contra o Império, pela Guerra do Paraguai etc., até a chegada do Marechal Hermes da Fonseca à presidência, sobre quem Schüler relata:

O marechal é um homem simples, lúcido, avesso a todo e qualquer luxo. Entrevistei-o algumas vezes e fiquei com a impressão de que é um sincero amigo da Alemanha e dos alemães. Obviamente seria uma tolice supor que essa amizade pudesse prejudicar outras nações amigas do Brasil. (Ibidem: 35, tradução nossa).

Schüler destaca as patentes militares dos personagens históricos - almirantado, marechalato, generalato etc. - e também dedica alguns trechos de seu livro a considerações sobre conflitos militares em que o Brasil se envolveu no decorrer de sua história, mas não sem dar especial atenção à participação de colonos alemães nesses eventos, por exemplo, na Guerra dos Farrapos, quando "muito sangue alemão foi derramado em terras do Rio Grande do Sul” (Ibidem: 15, tradução nossa). Explica que essa rebelião, iniciada em 1835 no Rio Grande do Sul e com uma duração de dez anos, declarou aquela província independente do Império. Com orgulho, Schüler também faz um relato sobre a participação de "voluntários alemães" em um exército equipado pelo Brasil, quando o ditador argentino General Rosas tentou conquistar o Uruguai no ano de 1851. Segundo seu relato, entre os voluntários alemães se encontravam “jovens cheios de vívido entusiasmo, membros do dissolvido exército de Schleswig-Holstein, bem como antigos combatentes da Revolução Alemã de 1848, que devido à sua convicção política tiveram de deixar sua pátria” (Ibidem: 15, tradução nossa). O autor abre um longo parêntese para relatar os feitos dos "homens corajosos", cuja memória reverencia em seu texto. Entre estes cita Karl von Koseritz, a quem apresenta a seguinte louvação:

Dentre os muitos que àquela época chegaram ao país, permitam-me destacar um nome, Karl von Koseritz, o altruísta e incansável líder dos alemães no Rio Grande do Sul. Para mim, era um amigo paternal, ensinou-me a amar o país e seus habitantes, inoculou-me a convicção de que todo aquele que aqui encontra uma segunda pátria tem o dever moral de não permanecer estrangeiro, mas de participar das lutas e dos destinos deste jovem 
povo que luta pelo progresso. Em 25 anos, enquanto minhas fracas forças, muitas vezes insuficientes, me permitiram, fiz, sempre que pude, o que Karl von Koseritz ensinou-me. Minha convicção custou-me alguns momentos difíceis e amargos, mas a ela, também no futuro, quero permanecer fiel, na firme convicção de que assim eu possa servir da melhor maneira a meu querido Brasil, assim como a minha não menos querida antiga pátria alemã. É verdade que este livro foi escrito com amor. Mas quem pode penetrar o espírito de um povo, quem pode aproximá-lo de outros povos, se não houver amor?" (Ibidem: 17, tradução nossa).

Essa descrição revela que Schüler, na verdade, queria servir a dois senhores: por um lado, era fiel à terra que o acolhera e, por outro, à sua terra natal. E esse amor pelos dois países era traduzido como um comprometimento, um dever no mínimo moral. Seu tom simpático ao militarismo é retratado pela insistência em trazer à baila o termo "lutas", seja em seu sentido denotativo, seja apenas metafórico. Ainda salienta a participação de alemães noutro conflito armado, ao explicar que na guerra travada pela Tríplice Aliança - entre Brasil, Argentina e Uruguai - contra o "ditador [paraguaio] Solano López”, o Brasil perdera muitos homens, sem esquecer de sublinhar que "alguns sul-rio-grandenses alemães encontraram um túmulo solitário no distante Paraguai” (Ibidem: 17, tradução nossa).

Concluindo suas considerações sobre a história brasileira, faz comentários sobre o governo de Hermes da Fonseca, enfatizando que não deverá ser uma fase livre de conflitos e preocupações. Ademais, aponta a participação do Brasil nas exposições de Saint Louis/Estados Unidos (1904), Bruxelas (1910) e Turim (1911), quando o país logrou apresentar ao mundo um quadro de suas incomensuráveis riquezas (Ibidem: 37, tradução nossa).

No tocante à demografia brasileira, Schüler faz uma apresentação técnica sobre a evolução da população do país sob a ótica da imigração estrangeira, recorrendo a tabelas, em geral publicadas pelo mesmo Centro Industrial do Brasil, entidade fundada no Rio de Janeiro em 15 de agosto de 1904, que em 1931 seria transformada na Federação das Indústrias do Rio de Janeiro. Entre as estatísticas apresentadas, sua preocupação se volta, por exemplo, para a quantidade de imigrantes de diversas nacionalidades (alemães, espanhóis, franceses, ingleses, italianos, poloneses, portugueses, russos, suecos, suíços etc.) registrados entre os anos de 1855 e 1910. O total não passava de 2.500 .000 imigrantes, mas, segundo Schüler, os números reais deviam chegar a 4.000.000, caso se considerasse que os números oficiais somente concerniam às pessoas que afirmavam ser imigrantes (Ibidem: 42ss, tradução nossa). Outrossim, esclarece que na década de 1840, marcada por conflitos e inquietações na Alemanha, a imigração alemã no Brasil mostrou- 
se proporcionalmente muito forte, principalmente após a Revolução de 1848 (Ibidem: 45, tradução nossa). Em números, teríamos, conforme os dados coletados por Schüler, os seguintes dados: em 1849 foram 2.179 imigrantes alemães, contra apenas 292 italianos. Porém, em 1888, chegaram apenas 782 alemães contra 104.358 italianos. De 1855 a 1880 foram 35.644 imigrantes alemães (3.295 austríacos) e 46.934 italianos. De 1855 até 1905 os números eram: 70.728 alemães, 45.888 austríacos e 1.043 .792 italianos. Em outro trecho, demostra entender a importância da presença alemã no Brasil por um ângulo bastante especial:

A parte do leão ficou com o estado de São Paulo, que também apresenta, todavia, o maior índice de retorno [de imigrantes] à Alemanha. Com um grande intervalo, vêm, na sequência, Rio Grande do Sul, Santa Catarina e Paraná. Em todos esses estados, todos os anos estão aparecendo mais cidadãos poloneses e italianos, superando o número de alemães, e isso poderá acarretar impactos danosos para o comércio alemão, se breve não houver uma transferência mais vigorosa de sangue alemão. (Ibidem: 43, tradução nossa)

Pode-se perceber, acima, a preocupação de Schüler com a balança comercial entre o Brasil e a Alemanha: segundo seu raciocínio, a presença alemã no Brasil deveria servir, de forma decisiva, à expansão comercial e industrial da Alemanha, garantindo a esse país trocas comerciais mais fortes com o Brasil. Se a Alemanha estava em $5^{\circ}$ lugar no ranking de países que mais exportavam para o Brasil entre 1874 e 1875 (Grã-Bretanha em 1º, França em $2^{\circ}$, Portugal em $3^{\circ}$, Estados Unidos em $4^{\circ}$ ), no ano de 1904 já ocupava a $2^{\circ}$ colocação (Grã-Bretanha em $1^{\circ}$, Estados Unidos em $3^{\circ}$ ), o que representava uma grande evolução nos números alemães (Ibidem: 145s, tradução nossa).

Ao discutir mais a fundo a importância dos imigrantes alemães para o Brasil e para a Alemanha, Schüler tornou mais evidentes tanto o zelo que devotava à alemanidade quanto o significado que esse conceito parecia ter para sua própria pessoa. Não se deve ignorar que Schüler, embora se autodeclarasse teuto-brasileiro, ali também se apresentava como uma espécie de representante da causa alemã. Vejamos algumas de suas palavras em defesa da alemanidade em território brasileiro:

Seja como for, é de se lamentar, no interesse tanto da Alemanha quanto do Brasil, que a imigração alemã não foi permanentemente mais forte. Com isso não quero defender uma emigração exagerada e indiscriminada de alemães para o Brasil; porém, uma emigração constante dentro de certos limites é simplesmente imprescindível para a preservação da alemanidade no Brasil, pois, sem aquela, esta inevitavelmente terá de vir à ruína. Sem sangue novo, sem entrada de inteligência, as colônias de expressão alemã muito dispersas no Sul do Brasil veem-se obrigadas a fundir-se com os elementos estrangeiros que as cercam e que lhes são numericamente superiores. Isso seria lamentável tanto do ponto de vista ideal quanto puramente prático, pois com isso a indústria alemã perde valiosas oportunidades de vendas. (Ibidem: 45, tradução nossa) 
Diante dessas palavras, pode-se indagar se a atividade de Schüler em apoio a um Instituto Teuto-Sul-Americano, mediante a difusão da cultura brasileira, seria em primeiro lugar no interesse e na defesa dos interesses brasileiros ou, na verdade, uma maneira de melhor estabelecer ligações com um potencial mercado para os produtores alemães. Segundo seu raciocínio, o Brasil também parecia servir como um país dotado de extensas terras à disposição de colonos alemães para que estes se estabelecessem no país, mas continuassem, de preferência, a falar sua língua e a manter sua própria cultura, seus ritos e comportamentos tipicamente alemães, sem se deixar mudar através dos "elementos estrangeiros" (brasileiros e de outras etnias, entenda-se). Isso se traduz numa inversão de valores: em princípio, eram os alemães os “elementos estrangeiros” aportados no Brasil.

Com satisfação, Schüler apresenta os números de imigrantes alemães entre 1905, quando chegaram apenas 192 alemães, e maio de 1911, quando o número subiu para 3 mil. Após apresentar uma série de tabelas com os números de imigrantes estrangeiros no Brasil, não se furta de indagar: “Quantos habitantes de língua alemã o Brasil quererá abrigar?" (Ibidem: 47, tradução nossa). Reconhecendo, ele próprio, que essa não é uma pergunta fácil de responder, ostenta alguns números que talvez esclareçam um pouco mais suas intenções quanto à alemanidade que desejava e defendia para o Brasil:

Para uma estimativa dessa natureza, tomemos por base primeiramente 110.000 imigrantes no período de 1835-1910; além disso, ponderemos que antigamente também não se registrava [no Brasil] uma imigração alemã considerável, que certamente foi bastante expressiva nos anos de 1825 a 1830; consideremos também que os imigrantes de todos os países germânicos aderiram à alemanidade, e que, de qualquer maneira, os alemães da Áustria e da Suíça precisam ser incluídos na alemanidade, coisa que a estatística não faz; e consideremos também que os números oficiais não contemplam todos os que vieram por conta própria para o Brasil, por exemplo, negociantes e artesãos; assim fazendo, não chegaremos a um número muito elevado, se estimarmos o total de imigrantes de expressão alemã no último século em 200.000 pessoas. (Ibidem: 48, tradução nossa)

Em sua estimativa do número total de imigrantes de língua alemã desde a chegada dos primeiros colonos alemães e a data da redação de seu livro, Schüler ainda apresenta dois importantes e surpreendentes dados: a alta taxa de natalidade (dez a doze filhos por família entre os colonos alemães) e a baixa taxa de mortalidade (não especificada em números). Com base nos números por ele levantados e/ou estimados, Schüler calculava que deviam estar vivendo 400 mil imigrantes alemães e seus descendentes no Brasil da primeira década do século XX. Com orgulho e, de certo modo, com um olhar complacente para o Brasil, Schüler também não considerava que esse número representasse um "perigo" para o Brasil, mas, ao contrário, um "ganho", afinal de contas, "o país deve a 
eles [aos imigrantes alemães] uma grande parte de seu admirável desenvolvimento". Além disso, "nenhum outro grupo de imigrantes pôs à disposição tantos produtores quanto os alemães" (Ibidem: 48, tradução nossa). Conforme relata, entre os alemães estabelecidos no Brasil havia agricultores, operários de fábrica treinados, artesãos, fabricantes, negociantes, artistas, profissionais de áreas acadêmicas e excelentes oficiais do Exército e da Marinha.

Em seu livro, Schüler ainda expressa um vasto conhecimento da Constituição Brasileira então em vigor (a Carta Magna republicana de 1891, vigente até 1926), dela pinçando alguns pontos relevantes para a temática dos imigrantes no país. Afirma:

Dentre as constituições dos países civilizados, nenhuma é tão liberal quanto a brasileira, nenhuma estende para os estrangeiros, com mais determinação e liberdade, as garantias salvaguardadas aos habitantes nacionais; nenhuma abre suas portas de modo mais amplo e hospitaleiro para oferecer uma nova pátria a todos que assim desejarem. (Ibidem: 93, tradução nossa)

O trecho supracitado faz-nos ver que a Constituição brasileira vigente àquela época também representava, na ótica de Schüler, um excelente motivo para que o projeto de alemanidade nas colônias alemãs pudesse ser alcançado. $\mathrm{O}$ autor ainda destaca mais um ponto relevante em seu programa de imigração alemã: "Não se exerce a menor pressão para que se adquira a cidadania brasileira; por outro lado, a obtenção da cidadania é facilitada a qualquer homem idôneo como não costuma ocorrer em praticamente nenhum outro país” (Ibidem: 93, tradução nossa). Esse detalhe bifacetado certamente parecia promissor para um projeto de estabelecimento de imigrantes alemães visando a manter intacta, o máximo possível, a alemanidade. Nesse contexto, o autor sublinha sua alegria em ver que os legisladores do Império Alemão já começavam a chegar à conclusão de que "os filhos da Mãe Germânia não podem perder, em nenhuma circunstância, sua cidadania imperial [ou seja: vinculada ao Império Alemão] e que eles nunca podem deixar de ser alemães". Entende, ainda, que as disposições então vigentes sobre essa matéria podiam ter sido corretas em anos anteriores, mas não mais o seriam "para o poderoso Império Alemão" (Ibidem: 102, tradução nossa). Assim, Schüler reforça a ideia de que todo alemão que se estabelecesse no estrangeiro deveria continuar a gozar do direito de obter, por motivos de convicção, consciência ou outras ponderações, a cidadania estrangeira, sem que isso implicasse em perda da cidadania imperial. Em sua concepção, nada mais lhe restava a não ser louvar a liberalidade das leis brasileiras sobre imigração e, ao mesmo tempo, saudar os novos ventos que deveriam facilitar a manutenção da nacionalidade alemã para emigrados.

Pandaemonium, São Paulo, v. 23, n. 39, jan.-abr. 2020, p. 25-56 
Incontáveis seriam os detalhes que aqui ainda poderíamos exibir sobre as ideias de Heinrich Schüler apresentadas em seu livro Brasilien. Ein Land der Zukunft. De modo resumido, é mister lembrar, nesta altura, que o livro homônimo de Stefan Zweig, enquanto obra de cunho eminentemente literário, trata dos temas brasileiros com um olhar extremamente humano e, de certo modo, idealizado, romantizado e sentimentalizado. Embora também estivesse preocupado com dados históricos e geográficos, Zweig mostrava-se mais afeito às questões sobre componentes antropológicas e sociológicas do Brasil, notadamente a mistura de raças e a paz [aparentemente] reinante entre os diferentes grupos étnicos. A Zweig interessava o projeto de paz que o Brasil representava, ainda mais para alguém que se encontrava interiormente destroçado pelos horrores da guerra e pelas atrocidades perpetradas contra diferentes minorias, por exemplo, contra os judeus. Schüler, por sua vez, ao realizar um estudo - original ou parcialmente fruto de plágio - aprofundado sobre o Brasil, em que considerava inúmeros aspectos históricos, geográficos, econômicos, jurídicos, estatísticos etc., parecia concentrar todos os seus esforços num projeto que garantisse a manutenção da alemanidade dos imigrantes de expressão alemã no Brasil; parecia apostar todas as suas cartas nas vantagens que principalmente a Alemanha - mas, de certo modo, também o Brasil - poderia tirar da presença de colonos alemães em um ambiente germânico e livre de influências advindas de "elementos estrangeiros" (SCHÜLER 1912: 45, tradução nossa).

\section{Heinrich Schüler ou Henrique Schüler?}

Ao iniciarmos a pesquisa para a consecução deste trabalho, tínhamos como certo que o autor do livro Brasilien. Ein Land der Zukunft (1912) usava apenas este nome como identidade: Heinrich Schüler. Todavia, ao consultarmos algumas obras em busca de alguma menção a seu nome, chamou-nos atenção a seguinte referência bibliográfica encontrada no livro publicado por Schulze (2016: 374, tradução nossa): "Schueler, Henrique/Roenick, Rodolfo (1936): Aufruf an die Brasilianer deutschen Blutes! [tradução livre: Conclamação aos brasileiros de sangue alemão!], Rio de Janeiro: Federação 25 de Julho". No mesmo livro e na mesma página de referências bibliográficas, Schulze (2016) apresenta os seguintes dados da edição do livro de Schüler a que recorrera em sua pesquisa: "Schüler, Heinrich (1924). Brasilien. Ein Land der Zukunft, 
Stuttgart/Berlin/Leipzig: Deutsche Verlagsanstalt”. Ora, a relação de identidade entre os dois prenomes - Henrique e Heinrich - e entre os dois sobrenomes - Schueler e Schüler - é patente, considerando-se a informação já mencionada sobre a Federação 25 de Julho que recebera o apoio do "cônsul Schüler" no Rio de Janeiro" (SCHUlze 2016: 103, tradução nossa). A partir daí, foi-nos possível realizar uma pesquisa em que considerássemos diferentes grafias do prenome e do nome de família do autor, lembrando que, para o sobrenome, já haviam sido encontradas diferentes grafias: Schuller (DINES, 2012), Schueler (SouSA, 1996) e Schüler (SCHUlZE, 2016; SCHÜLER, 1912).

Em uma matéria intitulada A colonização allemã no Brasil, o Jornal do Commercio (RJ), do dia 6/7/1935, mostra-nos a conexão direta de Rodolpho Roenick com a questão da imigração alemã no Brasil no seguinte texto:

\section{A colonização allemã no Brasil ${ }^{11}$}

Os teuto-brasileiros, a exemplo dos annos anteriores, pretendem commemorar condignamente a data de 25 do corrente [julho], quando, pela primeira vez, pisaram em sólo brasileiro os immigrantes allemães.

Há onze annos passados, o Governo do Rio Grande do Sul festejava o Centenario da colonização allemã naquelle Estado, tendo sido decretado feriado.

Dessa data em diante, todos os annos, a colônia allemã, os teuto-brasileiros e brasileiros amigos da cultura germanica promovem grandes solennidades civicas e sportivas, nessa data, tão significativa para o progresso do Brasil.

Tanto nos Estados de Santa Catarina, Paraná, São Paulo e E. do Rio, essa ephemeride foi sempre festejada com grande solennidade, sendo mesmo decretado feriado pelos Governos dos respectivos Estados.

As commemorações civicas deste anno prometem revestir-se de grande brilho, devendo realizar-se aqui no Rio, onde a colonia allemã é numerosa, grandes festas sportivas, além de uma sessão civica no Instituto Nacional de Musica. Ha grande enthusiasmo pela commemoração da data em todo o paiz.

Para essa solennidade, foi escolhida uma commissão da qual é representante no Rio o Sr. Rodolpho Henrique Roenick, encontrado á rua D. Gerardo no $42,3^{\circ}$ andar, nesta Capital. (JORNAL DO COMMERCIO 1935).

Um ano mais tarde, no dia 24/7/1936, véspera da festa comemorativa da imigração alemã, o mesmo jornal anuncia a programação da sessão cívico-musical promovida pela Federação 25 de Julho, no Teatro João Caetano, em homenagem a mais um aniversário da chegada dos primeiros colonos alemães. Para tal evento, o jornal noticiava a participação, dentre outros, do embaixador da Alemanha e do ministro da Áustria. Tanto

\footnotetext{
${ }^{11}$ Em todas as citações de jornais publicados em períodos em que vigorava outra ortografia no português brasileiro, será mantida a escrita da época.
} 
na divulgação da programação do ano de 1935 quanto na de 1936, não se vê no jornal, todavia, qualquer menção ao nome de H. Schüler.

Voltemos um pouco no tempo: a Gazeta de Notícias (RJ), em sua edição de 21 de setembro de 1919, publicou uma matéria intitulada Os estrangeiros na diplomacia nacional, contendo severas críticas a Henrique Schüler, que de certo modo lançam luz sobre a questão da diversidade de nomes de Heinrich, aliás, Henrique Schüler. Primeiramente, o diário carioca alude a uma matéria publicada em 20 de junho de 1919 no Le Brésil, um jornal então publicado em Paris, que replicara uma notícia-denúncia bastante grave - veiculada em um jornal de Bruxelas: "Um de nossos collaboradores, muito a par da vida diplomatica em Bruxellas, conta-nos o 'curriculum' de um allemão 'naturalizado' brasileiro - Herr Heinrich Schuler [sic], transformado em Henrique Schuler e que habitava Bruxellas antes da guerra". Aqui se obtém mais uma prova da duplicidade de nomes do cônsul teuto-brasileiro. Mas a matéria porá em dúvida a lealdade de Schüler ao Brasil, o que se pode depreender deste trecho:

Intitulava-se "membro do Instituto teuto-sul-americano". Ora, está na memória pública, que, no começo da [primeira] guerra [mundial], uma revolta de allemães rebentou no sul do Brasil, que forçou o governo a uma séria repressão dos tumultos, em que se verificou uma consequência do funccionamento do "Instituto teuto-sul-americano". (OS ESTRANGEIROS NA DIPLOMACIA NACIONAL 1919)

Importa-nos lembrar que, antes de eclodir a Primeira Guerra Mundial, já reinava entre alguns estudiosos grande preocupação acerca do "alemanismo" que poderia proliferar e dominar nos estados do sul do Brasil. Um dos autores a demonstrar claramente seus temores foi Silvio Romero (1910) em seu ensaio "O allemanismo no sul do Brasil: seus perigos e os meios de os conjurar". É digno de menção que Schüler tenta, em seu livro, negar o que chama de "conto da carochinha do perigo alemão", explanando que os colonos de origem germânica representavam apenas menos de $2 \%$ da população total do país (SCHÜLER 1912: 48, tradução nossa). Observe-se a continuação da matéria da Gazeta de Notícias:

Fosse o que fosse, o caso é que quando a guerra começou, Herr Schuler [sic] foi "addido" - não se sabe por quem - á... legação do Brasil. Era quem servia de intermediario entre a dita legação e a Kommandatur - o que fazia em lingua allemã, em cartas e em conversação, apesar de ser o francez o idioma diplomatico. Voltou a ser alemão... embora, permanecendo brasileiro, ou, melhor: em se fazendo brasileiro, nunca deixaria de ser allemão.

Desde ahi os allemães se consideravam em casa, na legação do Brasil, pois ahi encontravam esse excellente amigo Sr. Schuler [sic]. E os belgas, que, por ventura, deviam procural-a, tal como incautos brasileiros, de certo se não resignaram a ahi tomar 
café com Herr Conrad, um dos chefes do "departamento politico". Então, sobre a legação do Brasil, pesou nesse momento uma certa suspeição. (Ibidem)

Gerara-se, pois, uma suspeição contra Schüler, que podia estar servindo, naquele delicado período da história mundial, como agente duplo ou mesmo como traidor da pátria brasileira, da qual ele, na verdade, não era cidadão nato. Ao se reportar à Kommandatur, o quartel-general das tropas alemãs, Schüler, na qualidade de funcionário do corpo consular brasileiro, também dispunha de dados secretos do Estado que o acolhera, os quais poderia fornecer à sua pátria de origem. O jornal fornece mais detalhes:

Herr Schuler [sic] tinha um irmão official do exercito allemão. Sua filha casou, durante a guerra, com um outro official do mesmo exercito, em Bruxellas. Todavia, quando o Brasil rompeu com a Alemanha, Herr Schuler [sic] ausentou-se, o que muito fez rir aos seus amigos da Kommandatur. Herr Schuler [sic] foi para a Suissa.

Mais para adiante, porem, obteve um passaporte allemão, e voltou a Bruxellas, de onde, de novo partiu, pouco depois...

O Governo deve, sem dúvida, ter providenciado, afim de que esse pseudo brasileiro se consagre exclusivamente, de ora avante, - e longe de nós - ao desenvolvimento do "Instituto teuto-brasileiro". (Ibidem)

A matéria da Gazeta de Notícias conclui conclamando o então ministro das Relações Exteriores para que tomasse providências, visando a não mais permitir "a representação dessa inexplicável e escandalosa aleivosia”, ou seja, o fato de estrangeiros exercerem funções que somente deveriam ser confiadas a brasileiros natos. Desse modo, far-se-iam cumprir o texto da Constituição e as leis diplomáticas.

Embora algumas poucas referências tenham sido encontradas afirmando que Schüler era "cônsul alemão", através desta pesquisa foi possível encontrar, em diferentes jornais brasileiros, menções apenas à sua atuação como cônsul brasileiro. Como não foi possível encontrar uma biografia de H. Schüler, este trabalho se apoia mormente em notícias encontradas em jornais publicados no Brasil entre os anos de 1911 e 1939, visando, portanto, a contribuir com dados que ajudem a compor uma biografia do autor teuto-brasileiro. Uma das primeiras notícias de jornal envolvendo seu nome e digna de menção encontra-se no Jornal do Commercio do Rio de Janeiro, na edição do dia 4/12/1911, e informa que o Tribunal de Contas, por ordem de seu presidente, “ordenou o pagamento de 5:000\$ a Henrique Schueler pela $2^{a}$ prestação da publicação de um livro em língua allemã sobre o Brasil” (TRIBUNAL DE CONTAS, 1911). Pela data e pela temática do livro, pode-se concluir tratar-se do livro Brasilien. Ein Land der Zukunft. O mesmo jornal publica, em 19 de julho de 1912 (VARIAS NotiCIAS 1912), uma notícia informando 
que o ministro da Agricultura acabara de ser notificado sobre a fundação, em Berlim, da Liga Commercial Allemã-Brasileira [Deutsch-Brasilianischer Handelsband], uma iniciativa do alemão G. Fischsbart e do brasileiro Arthur Hermsdorf. Este último era gerente da Sociedade Teuto-Sul-Americana [Deutsch-Südamerikanische Gesellschaft], anteriormente criada sob a denominação de União Brasileira-Alemã [DeutschBrasilianischer Verein], da qual Schüler fora um dos sete fundadores. O jornal adianta que a Liga não era uma câmara de comércio, mas uma associação particular de industriais e comerciantes, mantida pelos membros através de cotas mensais de cem marcos. Notícia idêntica foi publicada pela Gazeta de Noticias, do Rio de Janeiro, em uma matéria intitulada Funda-se em Berlim a Liga Commercial Allemã-Brasileira (1912). No mesmo dia, em 23 de julho de 1912, o Jornal do Commercio também já divulgara uma nota concisa, informando que, por ordem do ministro da Agricultura, o Serviço de Povoamento organizara as informações e instruções solicitadas pelo Sr. Henrique Schüler, com o intuito de opor uma refutação às acusações feitas por jornais alemães contra a emigração para o estado de Santa Catarina. Como não logramos obter maiores dados sobre essa questão específica, aqui apenas especulamos que naquele ano Schüler já se empenhava em apoiar questões atinentes ao povoamento do sul do Brasil por imigrantes germânicos.

No dia 23 de julho de 1913, o Jornal do Commercio (RJ) divulgava mais um feito de H. Schüler em parceria com outros intelectuais da Alemanha e do Brasil:

Acaba de se fundar em Bonn, Alemanha, o Instituto Teuto Sul Americano, sociedade scientifica internacional que tem por principal escôpo o desenvolvimento das relações intellectuaes existentes entre a Alemanha e todos os paizes da América Latina.

No desenvolvimento de seu programa, o Instituto publicará boletins e periódicos, que interessem aos seus associados, estabelecendo o serviço de permuta de publicações não só entre elles como também entre os governos e sociedades doutas, auxiliando, além disso, a impressão de obras scientificas e litterarias em portuguez, hespanhol e alemão, e creando secções de informações e de estudo na Allemanha e na América Latina.

A propaganda dessa corporação foi confiada aos cuidados dos Drs. W. Borchers, Chr. Ekert, P. Gast, F. Luestner, E. Sapper Schneidewind, W. Siervers, G. Steinmmann, H. Schüler e M. de Oliveira Lima. (VARIAS NOTICIAS 1913)

Em 8 de janeiro de 1914, o jornal carioca A Noite informa que uma série de funcionários havia sido dispensada das comissões em que se encontravam na Europa; dentre eles estava Henrique Schüler (UMA PENCA DE DEMISSÕES 1914). Não há pormenores sobre esse tema. Sob o título "Ainda há muitos brasileiros na Bélgica", $A$ Noite também divulga, em 11 de dezembro 1915, a lista de brasileiros que haviam fixado 
residência naquele país e, apesar do conflito bélico em curso, ainda não haviam se decidido a retornar ao Brasil. Na lista são citados Henrique Schüler e família.

Em 16 de dezembro de 1919, a Gazeta de Notícias (RJ) informava que, "por portaria de 6 do corrente, foi concedida uma licença, para tratamento de saúde, ao auxiliar do consulado de Zurich, Sr. Henrique Schueler” (Noticias DO ItAMARATY 1919).

Em 11 de junho de 1923, o jornalista e poeta Ildefonso Falcão, que se encontrava em Bremen como auxiliar consular, publica uma matéria no jornal A Noite (O BRASIL NA UNIVERSIDADE DE HAMBURGO 1923) tecendo rasgados elogios a Henrique Schüler, destacando que, em 1921 e 1922, o funcionário do Itamaraty já proferira palestras na Universidade de Aachen, na Escola de Política de Berlim e na Universidade de Marburg. Num texto relativamente extenso, Falcão, sempre destacando a capacidade de Schüler, enumera os temas abordados pelo cônsul em suas preleções.

Sobre a carreira diplomática de Schüler, o Jornal do Commercio do Rio de Janeiro, em sua edição do dia 3 de junho de 1926 (MoviMENTo Diplomático E CONSUlar 1926), divulga que o então Ministro das Relações Exteriores assinara portaria promovendo a Cônsules de $2^{\mathrm{a}}$ Classe uma série de auxiliares de consulados; na lista também se encontrava o nome de Henrique Schuler [sic], promovido a Cônsul Adjunto de Hamburgo. Já uma matéria publicada pelo Correio Popular, de Campinas, em 6 de setembro de 1927 (O CONSUL SCHUELER ACTUA EM PRÓL DOS INTERESSES BRASILEIROS 1927), apresenta um breve currículo do cônsul "Henrique Schueler", que àquela época era cônsul adjunto do Brasil em Hamburgo. O Correio Popular adianta que seis edições de seu livro O Brasil terra do futuro - tradução do próprio jornal para o título original Brasilien. Ein Land der Zukunft - já haviam sido publicadas, e que a sétima se encontrava em preparação. Também destaca que Schüler antes fora vice-cônsul do Brasil em Bremen, de onde, durante três anos, costumava fazer o trajeto até Hamburgo, a fim de proferir conferências sobre o Brasil na universidade hamburguesa, sem auferir nenhum tipo de remuneração. Sacrificava suas horas livres para realizar este "trabalho patriótico", além de assumir todas as despesas com livros e demais materiais. $\mathrm{O}$ texto destaca igualmente seu trabalho como correspondente brasileiro entre os anos de 1911 e 1914, quando esteve à frente do já mencionado Reporter Brazileiro, que era publicado três vezes por semana e distribuído gratuitamente "para mais de mil jornais diários". Somente em 1912, teriam sido transcritas mais de 30 mil referências a notícias escritas por Schüler sobre o Brasil em sua página informativa. Segundo o jornal, o Reporter Brazileiro pouco onerava os 
cofres públicos e funcionava nos moldes de uma agência americana de notícias da época, servindo, assim, como excelente fonte de propaganda sobre o Brasil. A mesma reportagem também menciona uma obra de Schüler, publicada em 1914 em português, intitulada Atravez da Allemanha. Ainda conforme a mesma matéria, àquela época Schüler era reputado como um dos mais renomados especialistas brasileiros em economia nacional, gozando também de "grande e justo nome" como literato. Como reconhecimento por seus préstimos científicos, a Universidade de Hamburgo conferiulhe a "Medalha de Ouro", uma distinção antes concedida apenas a dois outros brasileiros, “ao Dr. Miguel Couto e ao Dr. Aragão". Por fim, a matéria do Correio Popular ainda informa duas novidades: a) naquele momento Schüler estava começando a instalação de uma exposição permanente de produtos brasileiros em Hamburgo; e b) poucas semanas antes, naquele ano de 1927, fora publicado Sob o Cruzeiro do Sul, seu romance histórico, cujo título original em alemão é Unterm Kreuz des Südens, lançado pela editora Deutsche Verlags-Anstalt, em Berlim.

O Jornal do Commercio do dia 7 de setembro de 1929 noticia que Henrique Schüler, cônsul adjunto do Consulado Geral do Brasil em Hamburgo, era aguardado com sua família, proveniente de Hamburgo no Cap Arcona ${ }^{12}$ (VIAJANTES 1929). Sobre sua família, também $O$ Jornal, do Rio de Janeiro, publica naquele mesmo dia uma nota informando que o Sr. Henrique Schüler, "que vem em gozo de férias regulamentares", está sendo esperado, “com senhora e filha”, pelo Cap Arcona (HósPEDES E VIAJANTES 1929). Por seu turno, o jornal Correio Paulistano informa, em 12 de abril de 1930 (BRASIL ECONÔMICO E COMERCIAL 1929), que o cônsul adjunto do Brasil em Hamburgo, com retorno a seu posto diplomático previsto até o dia 15 daquele mês, estava à disposição de quaisquer interessados, no horário de 15 a 15h, no Ministério das Relações Exteriores, mais precisamente na Sala dos Serviços Econômicos e Comerciais. Três dias depois, em 15 de abril de 1930, o mesmo jornal noticia que o Sr. Henrique Schuler [sic], cônsul do Brasil em Hamburgo, estava retornando, no Sierra Cordoba ${ }^{13}$, a seu posto, após uma estadia de "seis meses em gozo de férias regulamentares" (CÔNSULES BRASILEIROS 1930).

Na edição do dia 6 de novembro de 1935, O Jornal, do Rio de Janeiro, em matéria intitulada As condições econômicas da Alemanha - Hitler (1935), noticiou que, conforme fora amplamente divulgado antes, tivera lugar no dia 25 de outubro de 1935 a conferência

\footnotetext{
${ }^{12}$ Transatlântico de luxo alemão.

${ }^{13}$ Navio do Lloyd alemão.

Pandaemonium, São Paulo, v. 23, n. 39, jan.-abr. 2020, p. 25-56
} 
do Dr. Ascendino da Cunha sobre questões econômicas da Alemanha de Hitler, no âmbito do Instituto Teuto-Brasileiro de Alta Cultura. Cabe esclarecer que esse instituto foi criado no Rio de Janeiro no dia 12 de abril de 1930, como informa o Jornal do Commercio em sua edição dos dias 15 de junho de 1930, tendo Schüler como um de seus fundadores (Instituto Teuto-Brasileiro de Alta Cultura 1930).

No dia 31 de julho de 1936, uma nota no Jornal do Commercio indica que o Sr. [não se mencionava o título "cônsul"] Henrique Schuler [sic] e o sr. Rodolpho Roenick estiveram no Palácio do Catete, a fim de agradecerem pessoalmente ao Presidente da República por ter-se feito presente às comemorações da Federação 25 de Julho pelo dia da imigração alemã (VARIAS NOTICIAS 1936). O jornal também informa que um seleto grupo de professores, juristas, diplomatas, economistas etc. atendeu ao chamado, mencionando, dentre outros, o Sr. Dr. Henrique Schuler [sic], "antigo cônsul” geral do Brasil em Hamburgo. Por seu turno, uma nota do Correio Paulistano, datada de 25 de março de 1937, informa que embarcaram naquela cidade [Santos], com destino ao Rio, Arthur Otto e o "cônsul” Henrique Schuler [sic] (OS QUE VIAJAM PELO AR 1937). Esses dados não nos permitem inferir que Schüler assim foi denominado pelo jornal apenas por força do antigo título de cônsul com que antes era conhecido; por outro lado, o jornal tampouco dá margem a que se entenda que Schüler fazia parte do Corpo Consular alemão no Rio. Em sua edição dos dias 9 e 10 de janeiro de 1939, o Jornal do Commercio noticia um caso de desfalque cometido por um alto funcionário do consulado brasileiro em Londres (APPELAÇÃo CRIMINAL No 9.768 1939). Entre os depoimentos arrolados pela Justiça, figurava a opinião do "cônsul Schuler [sic]" sobre esse caso.

\section{Considerações finais}

Mediante este estudo, tentou-se mostrar que a falta de bastantes pormenores sobre Heinrich Schüler - aliás, Henrique Schüler -, autor de Brasilien. Ein Land der Zukunft (1912), acarreta a difusão de uma imagem fragmentada e lacunar desse teuto-brasileiro dividido entre dois mundos. Como revelaram nossas pesquisas feitas sobretudo em jornais brasileiros e teuto-brasileiros, Schüler ora aparece como uma figura simpática ao Brasil, sua segunda pátria, ora como um homem interessado em abrir espaço, neste país, para os interesses da Alemanha, sua terra natal. Tais interesses eram de cunho econômico, 
comercial, industrial, cultural, político e ideológico. Se, ao publicar na Alemanha seu livro sobre o Brasil, Schüler já defendia ideias que apoiavam a expansão do alemanismo em nosso país, há de se imaginar que nos anos 1930, com a ascensão de Hitler ao poder, a atuação do cônsul brasileiro tenha sido marcante no centro dos ideais de alemanidade defendidos por seus pares. Stefan Zweig, por seu turno, escreveu um livro homônimo com intenções diferentes das de Schüler: seu interesse certamente não devia ser vender uma imagem do Brasil para o estrangeiro, mas divulgar para o mundo uma outra visão de vida que, a seus olhos, parecia ter como base a paz e a harmonia étnica, cultural e política. Mas não devemos ignorar que sua visão era a de um ficcionista, um biógrafo apaixonado, que a qualquer momento podia ser atingido pelo coup de foudre. Registre-se, aqui, que ainda não logramos encontrar nenhum indício de que Zweig tenha lido o livro de Schüler.

De certo modo, além do título dos dois livros, mais dois aspectos conectam ambos os autores. O primeiro aspecto diz respeito a possíveis acusações de plágio: contra Zweig, poder-se-ia alegar ter ele adotado, em sua monografia-biografia do Brasil, de 1941, um título idêntico ao escolhido por Schüler para sua monografia brasileira, publicada três décadas antes da obra do austríaco; e, contra Schüler, alegou-se ter ele, em grande parte, vertido para o alemão - indiretamente via francês - a documentação compilada pelo Centro Industrial do Brasil, além de ter-se apropriado do conteúdo elaborado pelo cônsul E. Heinze sobre a erva-mate. Todavia, o próprio título do livro de Schüler, como já apontara Dines (2012: 460), nada teria de original, se considerarmos a publicação, em 1909, do livro do holandês N. R. de Leuw. O segundo aspecto em comum concerne à acusação de que cada uma daquelas obras teria atendido a fins de publicidade e divulgação, e que seus autores poderiam e/ou deveriam ter auferido algum ganho extraordinário, fosse este pecuniário ou de qualquer outra natureza. Analisando-se as matérias sobre o cônsul Henrique Schüler, facilmente se nota sua atuação em dois frontes: Brasil e Alemanha. Se ora representava este, ora aquele país, essa participação em duas searas distintas decerto contribuía para que desfrutasse de trânsito relativamente livre entre a diplomacia alemã e a brasileira. É de se supor que isso lhe proporcionasse alguns ganhos e/ou privilégios, não necessariamente em forma de pecúnia, mas no mínimo de prestígio. Ildefonso Falcão atestou, em 1923, que Schüler abordava diversos temas sobre o Brasil nas preleções e conferências proferidas na Alemanha. Ademais, o Correio Popular, em 1927, elogiou o "trabalho patriótico" realizado pelo cônsul brasileiro que preparava e ministrava suas aulas na Universidade de Hamburgo graciosamente. Tal 
"trabalho patriótico" também podia ter o mesmo caráter bivalve da atuação de Schüler: em seu duplo papel, abria uma espécie de espacate político-diplomático e servia a dois senhores. Quanto a Zweig, se houve alguma intenção de fazer propaganda para obter algum lucro, seu ganho primordial fora, em primeira linha, tão-somente salvar a pele da morte iminente na câmara de gás, e não simplesmente servir ao então ditador Getúlio Vargas. Mas sequer essa possível ambição proporcionou-lhe grandes resultados, pois poucos meses durou sua tão sonhada vida em paz, livre da guerra e da violência, entregando-se ao suicídio.

Outro fator ligado ao comportamento de Schüler salta bastante aos olhos: sua insistência em sublinhar e dar voz à alemanidade no Brasil, em destacar com tintas muito fortes a necessidade de firmar a alemanidade em solo brasileiro, inclusive recomendando o envio de "sangue novo alemão" para evitar que os colonos germanófonos fossem superados por "elementos estrangeiros" em pleno Brasil. Também estarrece a forma como costurava e alinhava um projeto para que a Alemanha obtivesse cada vez mais espaço no ranking internacional de exportadores/importadores em relação ao parceiro Brasil. Entendemos que, no raciocínio de Schüler, sua pátria de origem precisava consolidar uma firme posição comercial junto ao Brasil e fazer-se cada vez mais imprescindível para que o Brasil permanecesse dependente daquela que era uma potência mundial consolidada.

Estamos cônscios de que novos detalhes sobre Schüler foram trazidos à luz nesta pesquisa, mas lamentamos não podermos contribuir com alguns simples dados que normalmente fazem parte do gênero textual "biografia": data e local de nascimento ${ }^{14} \mathrm{e}$ morte do duplo personagem Heinrich/Henrique Schüler, que, malgrado suas dubiedades - ou quiçá justamente devido a isso - também deve ocupar um lugar nos estudos interculturais desenvolvidos por brasilianistas, lusitanistas e germanistas. Outrossim, como esta pesquisa não logrou comprovar que Schüler em algum momento foi cônsul alemão no Rio de Janeiro, também entendemos que ainda há fios a serem puxados para finalizar-se um tecido biográfico sobre esse homem. Embora alguns autores insistam em denominá-lo "cônsul alemão", nas inúmeras matérias jornalísticas que analisamos durante este estudo não encontramos uma vez sequer uma referência ao "cônsul alemão Heinrich Schüler", mas sempre ao "cônsul brasileiro Henrique Schüler".

\footnotetext{
${ }^{14}$ No livro de Heinrich Schüler dedicado à Imperatriz Leopoldina (SCHÜLER, 1954), há uma foto do escritor com a seguinte legenda: "der 90-jährige Verfasser" [o autor de 90 anos]. Como o livro foi publicado em 1954, calcula-se que Schüler tenha nascido por volta de 1864.
} 
Romão, T. L. C. - Brasilien. Ein Land der Zukunft

\section{Referências bibliográficas}

A COLONIZAÇÃO ALlEMÃ NO BRASIL. Jornal do Commercio, Rio de Janeiro, ano 108, nº 236; 6 jul. 1935.

AINDA HÁ MUITOS BRASILEIROS NA BÉLGICA. Jornal A Noite, Rio de Janeiro, ano 1, n. 1427, 11 dez. 1915.

APPELAÇÃo CRIMINAL No 9.768. Jornal do Commercio, Rio de Janeiro, ano 112, nº 86; 9 e 10 jan. 1939.

AS CONDIÇÕES ECONÔMICAS DA ALEMANHA - Hitler. O Jornal, Rio de Janeiro, ano XVII, $\mathrm{n}^{\circ}$ 5.023; 6 nov. 1935.

BISPO, A. A. Os teuto-brasileiros e a transformação da imagem do Rio de Janeiro "Brasil: Terra do Futuro" de Heinrich Schüler. Revista Brasil-Europa: Correspondência EuroBrasileira, [s. l.], v. 153, n. 13, 2015. Disponível em: http://revista.brasileuropa.eu/153/Heinrich-Schueler-1911.html. Acesso em: 25 set. 2019.

BRIESEMEISTER, D. Wege und Motive der Beschäftigung mit dem Portugiesischen in Deutschland: Ein geschichtlicher Überblick. Deutscher Lusitanistenverband, [s. l.], 2014. Disponível em: http://lusitanistenverband.de/wp-content/uploads/sites/9/BriesemeisterBetrachtungen_zur_Lusitanistik.pdf . Acesso em: 14 mar. 2019.

CÔNSULES BRASILEIROS QUE VÃo REASSUMIR SUAS FUNCÇÕES. Correio Paulistano, São Paulo, ano $76, \mathrm{n}^{\circ} 23.835,15$ abr. 1930.

CostA, S. R. Dicionário de gêneros textuais. Belo Horizonte: Autêntica, 2012.

DINES, A. Morte no paraíso: a tragédia de Stefan Zweig. Rio de Janeiro: Rocco, 2012.

DreKonjA-KoRnAt, G. Literatur und Politik: Die brasilianische Melange. Blätter für die deutsche und internationale Politik, Berlin, v. 10, 2013, p. 115-120. Disponível em: https://www.blaetter.de/archiv/jahrgaenge/2013/oktober/literatur-und-politik-diebrasilianische-melange. Acesso em: 14 mar. 2019.

ECKL, M. "Größtes zärtliches Brasilien" - Das Brasilienbild in den Werken von Heinrich Eduard Jacob. Pandaemonium Germanicum, São Paulo, v. 14, 2009, p. 54-83.

FORSTER, M. T. D. Oliveira Lima e as relações exteriores do Brasil: o legado de um pioneiro e sua relevância atual para a diplomacia brasileira. Brasília, DF: Fundação Alexandre de Gusmão, 2011.

FundA-SE EM BERLIM A Liga COMMERCIAL ALLEMÃ-BRASILEIRA. Gazeta de Noticias, Rio de Janeiro, ano XXXVI, nº 241; 23 jul. 1912.

HÓSPEDES E VIAJANTES. O Jornal, Rio de Janeiro, ano XI, nº 3.313; 7 set. 1929.

Instituto Teuto-Brasileiro De Alta Cultura. Jornal do Commercio, Rio de Janeiro, ano $103, n^{\circ} 89 ; 14 / 15$ jun. 1930.

MOVIMENTO DIPLOMÁTICO E CONSULAR. Jornal do Commercio, Rio de Janeiro, ano 99, n 152 ; 3 jun. 1926.

O BRASIL NA UnIVERSIDADE DE HAMBURGO. Jornal A Noite, Rio de Janeiro, ano XIII, n. [ilegível], Rio de Janeiro, 8/1/1914;

O CONSUl SCHUEler ACTUA EM PRÓL DOS INTERESSES BRASILEIROS. Correio Popular, Campinas, ano 1, n. 2, 6/9/1927.

Os ESTRANGEIROS NA DIPLOMACIA NACIONAL. Gazeta de Notícias, Rio de Janeiro, ano XLIV, ${ }^{\circ}$ 261; 21 set. 1919.

OS QUE VIAJAM PELO AR. Correio Paulistano, São Paulo, ano LXXXIII, nº 24.855; 25 mar. 1937.

Romero, S. "O allemanismo no sul do Brasil". In: Romero, S. Provocações e debates: contribuições para o estudo do Brazil social. Porto: Livraria Chardron, 1910, p. 115-169.

Pandaemonium, São Paulo, v. 23, n. 39, jan.-abr. 2020, p. 25-56 
RothfuSS, D. Jornais de imigrantes alemães. Instituto Martius-Staden, São Paulo, 2014. Disponível em: http://www.martiusstaden.org.br/conteudo/detalhe/148/bibliotecadigital-unesp. Acesso em: 25 set. 2019.

SCHÜLER, H. Brasilien: Ein Land der Zukunft. Stuttgart: Deutsche Verlags-Anstalt, 1912.

SCHÜLER, H. Brasilien von heute. Berlim: Dreyer \& Co., 1910.

SCHÜLER, H. Dona Leopoldina: Erste Kaiserin von Brasilien: Schutzherrin der deutschen Einwanderer. Porto Alegre: Instituto Beneficente e Genealógico Frederico Mentz, 1954.

SCHULZE, F. Auswanderung als nationalistisches Projekt. ,Deutschtum' und Kolonialdiskurse im südlichen Brasilien: 1824-1941. Colônia: Böhlau Verlag, 2016.

SousA, C. H. M. R. Retratos do Brasil: Hetero-imagens literárias alemãs. São Paulo: Arte e Cultura, 1996.

TRIBUnal De CONTAS. Jornal do Commercio, Rio de Janeiro, ano 85, n 338;5 dez. 1911.

TroppmaIR, R. (ed.). Neue Südamerika-Literatur. Deutsche Zeitung, São Paulo, ano XV, n. 88, 15 abr. 1912.

UMA PENCA DE DEMISSÕES. A Noite, Rio de Janeiro, ano IV, nº 777; 8 jan. 1914.

VARIAS NOTICIAS. Jornal do Commercio, Rio de Janeiro, ano 86, nº 200; 19 jul. 1912.

VARIAS NOTICIAS. Jornal do Commercio, Rio de Janeiro, ano 87, nº 203; 23 jul. 1913.

VARIAS NOTICIAS. Jornal do Commercio, Rio de Janeiro, ano 109, nº 259; 31 jul. 1936.

ViAJANTES. Jornal do Commercio, Rio de Janeiro, ano 102, no 2147 set. 1929.

ZWEIG, S. Brasil: país do futuro. Tradução: Odilon Gallotti. Sintra: Colares Editora, [s. d.].

ZwEIG, S. Brazil: land of the future. Tradução: Andrew St. James. New York: The Viking Press, 1941.

ZwEIG, S. Brazil: land of the future. Tradução: Andrew St. James. London: Cassell \& Co., [1942].

ZwEIG, S. Brasil: país do futuro. Tradução: Odilon Gallotti. Rio de Janeiro: Delta, 1960.

ZWEIG, S. Die Welt von gestern: Erinnerungen eines Europäers. Frankfurt am Main: S. Fischer, 1982.

ZWEIG, S. Tagebücher. Frankfurt am Main: S. Fischer Verlag, 1984.

ZWEIG, S. Brasil - ein Land der Zukunft. Frankfurtam Main.: Insel Verlag, 1997.

ZWEIG, S. Brazil: a land of the future. Tradução: Lowell A. Bangerter. Riverside: Ariadne, 2000.

ZWEIG, S. Le Brésil, terre d'avenir. Tradução: Jean Longeville. Querigny: Éditions de l'Aube, 2005.

ZWEIG, S. Brasil: país de futuro. Tradução: Alfredo Cahn. Barcelona: Cahoba, 2006a.

ZweIG, S. Brasil: um país do futuro. Tradução: Kristina Michahelles. Porto Alegre: L\&PM, 2006b. 